J URARARASI TEKIIK SIPIL 


\section{JURNAL GRADASI TEKNIK SIPIL POLITEKNIK NEGERI BANJARMASIN}

Jurnal Gradasi Teknik Sipil diterbitkan oleh Pusat Penelitian dan Pengabdian Kepada Masyarakat Politeknik Negeri Banjarmasin. Ruang lingkup makalah meliputi Bidang Teknik dan Manajemen dengan konsentrasi Bidang Transportasi, Geoteknik, Struktur, Keairan dan Manajemen Konstruksi. Isi makalah dapat berupa penyajian isu aktual di bidang Teknik Sipil, review terhadap perkembangan penelitian, pemaparan hasil penelitian, dan pengembangan metode, aplikasi, dan prosedur di bidang Teknik Sipil. Makalah ditulis mengikuti panduan penulisan.

\section{Penanggung Jawab}

Nurmahaludin, ST, MT.

\section{Dewan Redaksi}

Ketua $\quad$ : $\quad$ Dr. Fitriani Hayati, ST, M.Si.

Anggota $\quad$ : $\quad$ Riska Hawinuti, ST, MT.

Nurfitriah, S.Pd, MA.

Ir. Rusliansyah, M.Sc.

\section{Reviewer}

Dr. Ir. Yanuar Jarwadi Purwanto, MS. (Institut Pertanian Bogor)

Dr. Ir. Achmad Rusdiansyah, MT. (Universitas Lambung Mangkurat)

Dr. Ir. M. Azhar, M. Sc. (Institut Sains dan Teknologi Nasional)

Dr. Ir. Endang Widjajanti, MT. (Institut Sains dan Teknologi Nasional)

Joni Irawan, ST, MT. (Politeknik Negeri Banjarmasin)

Yusti Yudiawati, ST, MT. (Politeknik Negeri Banjarmasin)

\section{Editing dan Tata Bahasa}

Nurfitriah, S.Pd., MA.

\section{Desain dan Tata Letak}

Abdul Hafizh Ihsani

\section{Alamat Redaksi}

Jurusan Gradasi Teknik Sipil Politeknik Negeri Banjarmasin, Jl. Brigjen H. Hasan Basri 70123 Banjarmasin Telp/Fax 0511-3307757; Email: gradasi.tekniksipil@poliban.ac.id 


\section{JURNAL GRADASI TEKNIK SIPIL}

\section{DAFTAR ISI}

Perencanaan Struktur Atas Jembatan Komposit Sungai Nipah Desa Darul Aman Kecamatan Rupat ...( 1 - 9 )

Nur Aspaliza, Indriyani Puluhulawa, Armada

Perencanaan Jembatan Rangka Baja Pelengkung Sungai Liong ...( 10 - 21 )

Febry Suhendra, Faisal Ananda, Alamsyah

Pengaruh Agregat Setempat Terhadap Nilai Indeks dan Biaya pada Analisa Satuan

Pekerjaan Beton f'c $20 \mathrm{MPa}$... ( 22 - 29 )

Muhammad Humaidi, Khairil Yanuar, Aunur Rafik

Pengaruh Posisi, Jumlah Layer Dan Mutu Kayu Terhadap Balok Laminasi Kayu Mahang Dan Kayu Meranti ...( 30 - 35 )

Indriyani Puluhulawa

Pengaruh Supeltas Terhadap Tingkat Pelayanan Simpang Jalan Trans KalimantanKomplek Griya Permata ...( $36-44)$

Riska Hawinuti

Perancangan Lapis Pondasi Agregat Tanpa Penutup Aspal Gradasi Batas Tengah Menggunakan Claystone ...( 45 - 54 )

Ahmad Norhadi, H. Muhammad Fauzi, Akhmad Marzuki, Zuraida 


\title{
Perencanaan Struktur Atas Jembatan Komposit Sungai Nipah Desa Darul Aman Kecamatan Rupat
}

\author{
Nur Aspaliza ${ }^{1}$, Indriyani Puluhulawa ${ }^{2}$, Armada $^{3}$ \\ ${ }^{1}$ Mahasiswa Jurusan Teknik Sipil Politeknik Negeri Bengkalis \\ ${ }^{2,3}$ Dosen Jurusan Teknik Sipil Politeknik Negeri Bengkalis \\ e-mail:*1nuraspaliza7@gmail.com (corresponding author), ${ }^{2}$ indriyani@polbeng.ac.id, ${ }^{3}$ armada@polbeng.ac.id
}

\begin{abstract}
Abstrak
Jembatan Desa Darul Aman pada awalnya merupakan jembatan struktur kayu yang menghubungkan pemukiman masyarakat dengan pelabuhan dan juga perkebunan milik warga setempat. Kondisi jembatan tersebut saat ini sudah tidak layak dilewati karena struktur kayu pada jembatan sudah mengalami pelapukan yang parah, sehingga sangat beresiko jika dipaksakan untuk dilewati kendaraan terus menerus dan akan menimbulkan kerusakan yang semakin parah. Untuk itu direncanakanlah jembatan baru dengan menggunakan struktur komposit antara gelagar baja dan slab beton. Perencanaan ini mengacu pada SNI T-02-2005 untuk pembebanan jembatan dan SNI T-03-2005 untuk perencanaan struktur baja. Adapun yang direncanakan adalah meliputi slab jembatan, gelagar, diafragma dan perletakan elastomer jembatan.

Dari hasil perencanaan diperoleh profil gelagar baja yang digunakan Baja WF 800.300.14.26 mm dengan jarak antar girder 1,125 m. Digunakan diafragma baja profil siku $70 \times 70 \times 7 \mathrm{~mm}$ dengan jarak antar diafragma $4 \mathrm{~m}$, diameter perletakan elastomeric adalah $175 \times 300 \times 12 \mathrm{~mm}$.
\end{abstract}

Kata kunci-Jembatan komposit, Perencanaan, Struktur atas.

\begin{abstract}
The Darul Aman Village Bridge was originally a wooden bridge connecting community settlements with harbor and plantation areas. The current condition of the bridge is not worth crossing because the wooden structure on the bridge has severe weathering, so it is very risky if it forced to be passed through by vehicles continuously and will cause further damage. For this purpose, a new bridge is planned using a composite structure between steel girder and concrete slab. This plan refers to SNI T-02-2005 for loading bridge and SNI T-03-2005 fot steel structure planning. The planning includes bridge slab, girders, diaphragms and bridge elastomeric placement.

From the result of the planning, the steel girder profile is using WF 800.300.14.26, with a gap between $1,125 \mathrm{~m}$. The steel angles profile diaphragm is $70.70 .7 \mathrm{~mm}$ with a $4 \mathrm{~m}$ diaphragm gap, the elastomeric placement diameter is $175.300 .12 \mathrm{~mm}$.
\end{abstract}

Keywords - composite bridge, planning, upper structure

\section{PENDAHULUAN}

a. Latar Belakang

Definisi jembatan menurut Supriyadi 1997 adalah bangunan yang memungkinkan jalan untuk menghubungkan atau menyilangkan sungai/saluran air lembah atau menyilang jalan lain yang tidak sama tinggi permukaannya Secara umum bentuk dan bagian suatu struktur jembatan dapat dikelompokkan menjadi 4 empat bagian utama yang meliputi struktur bagian atas dan struktur bagian bawah bangunan pelengkap pengaman jembatan serta trotoar. Struktur atas jembatan yang dimaksud adalah bagian-bagian jembatan yang memindahkan beban-beban lantai jembatan ke perletakan arah horisontal. Lantai jembatan merupakan bagian dari jembatan yang langsung menerima beban lalulintas kendaraan, pejalan kaki dan beban yang membebaninya secara langsung. 
Kondisi jembatan Desa Darul Aman saat ini sudah rusak dengan material kayu yang sudah lapuk dan berlubang serta lantai jembatan agak miring. Hal ini kemungkinan bisa menyebabkan runtuhnya jembatan yang akan membahayakan pengguna jembatan tersebut. Rusaknya jembatan biasanya disebabkan oleh faktor beban lalu lintas yang melewati jembatan seperti mobil pengangkut kelapa sawit ataupun faktor lingkungan lainnya. Oleh karena itu perlu dilakukan perencanaan struktur jembatan baru yang dapat melayani kebutuhan lalu lintas masyarakat setempat yang dalam hal ini direncanakan jembatan struktur komposit.

Adapun tujuan dari perencanaan ini adalah untuk mendapatkan hasil perencanaan pembebanan dan analisa struktur atas jembatan, mendapatkan dimensi gelagar baja yang mampu memikul beban pada jembatan tersebut serta gambar hasil desain struktur atas jembatan tersebut. For this purpose

\section{b. Komposit}

Konstruksi komposit merupakan sebuah konstruksi yang materialnya terdiri dari perpaduan dua jenis material yang tidak sama atau berbeda sifatnya (Thamrin 2012). Kedua jenis material tersebut digabungkan sedemikian rupa supaya bisa bekerja sama dalam memikul beban. Konstruksi seperti ini umumnya ditemukan pada struktur jembatan berupa gabungan pada pelat lantai yang terdiri dari material beton dan gelagar dari material baja.

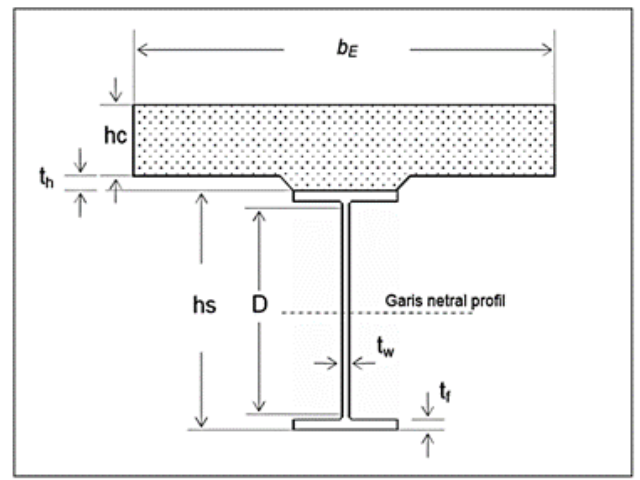

Gambar 1 Penampang komposit (Sumber:Thamrin, N, 2012)

Perencanaan komposit mengasumsi bahwa baja dan beton bekerja sama dalam memikul beban yang bekerja, sehingga akan menghasilkan desain profil/elemen yang lebih ekonomis. Selain itu struktur komposit juga mempunyai beberapa keunggulan, diantaranya adalah lebih kuat (stronger) dan lebih kaku (stiffer) dari pada struktur nonkomposit.

\section{METODE PENELITIAN}

A. Tahapan Penelitian

Adapun tahapan penelitian dalam penyusunan laporan ini adalah:

\section{a. Observasi}

Observasi merupakan kegiatan dengan cara survei ke lokasi jembatan selama satu hari untuk meninjau serta mengumpulkan data yang berkaitan untuk memperoleh panjang jembatan serta lebar lajur jalan yang dipakai serta pengamatan terhadap kondisi jembatan yanhg ditinjau.

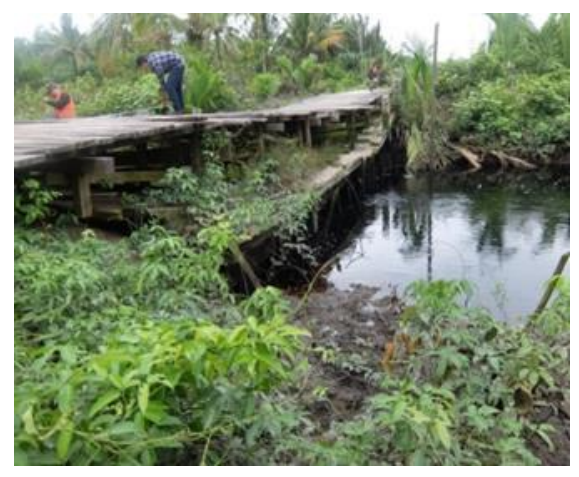

Gambar 2 Kondisi jembatan Sungai Nipah (Sumber: Dokumentasi kondisi jembatan saat ini)

\section{b. Metode Perencanaan}

Untuk mendapatkan hasil desain yang sesuai dengan aturan yang ditetapkan, maka perencanaan ini dilakukan dengan mengacu pada SNI T-02-2005, SNI T-03-2005 dan SNI T-12-2004, serta beberapa literatur lain yang diperlukan dalam perencanaa jembatan komposit yang dapat berupa buku cetak, jurnal dan referensi lain yang dapat diakses dilaman internet.

\section{c. Metode Perancangan}

Adapun metode desain yang direncanakan adalah merencanakan struktur atas jembatan dan perletakannya yang meliputi: 
1. Analisa pembebanan pada struktur atas berdasarkan SNI T-02-2005.

2. Analisa struktur meliputi perencanaan struktur atas berdasarkan SNI T-12-2004.

3. Perencanaan tiang sandaran.

d. Tahapan perencanaan

Adapun tahapan yang dilakukan adalah sebagai berikut:

1) Langkah awal dalam perencanaan adalah mendapatkan dimensi jembatan yang diperlukan sesuai kondisi lapangan. Untuk itu dilakukan observasi dengan cara melakukan pengukuran yang meliputi pengukuran potongan melintang sungai di lokasi jembatan.

2) Menghitung Analisa beban slab lantai jembatan berdasarkan SNI T-02-2005. Mutu beton yang digunakan adaah K-300 dengan kuat tekan beton 25 Mpa. Adapun analisa yang dihitung adalah Beban mati (berat sendiri, beban mati tambahan dan beban akibat aksi lingkungan (beban angin dan beban temperatur), kemudian menghitung momen pada slab jembatan dan kombinasi pembebanan pada slab jembatan tersebut. Setelah pembebanan didapat maka dilanjutkan dengan menghitung penulangan slab jembatan yang meliputi perhitungan tulangan lentur positif, tulangan lentur negatif, kontrol lendutan yang terjadi pada slab dan kontrol tegangan geser, selanjutnya menghitung pembebanan pada jembatan.

3) Selanjutnya adalah perhitungan kekuatan gelagar komposit. Kuat leleh baja (fy) $390 \mathrm{mPa}$. Modulus elastisitas baja (Es) $200000 \mathrm{mPa}$. Adapun perhitungannya adalah beban tetap, beban lalu lintas (beban Truk, beban lajur D dan beban titik), gaya rem, beban akibat pengaruh lingkungan (beban angin, beban temperatur, beban gempa), beban akibat susut dan rangkak dan beban akibat gesekan perletakan serta kombinasi pembebanan pada jembatan. Kemudian dilanjutkan dengan menghitung kekuatan gelagar komposit sesuai data profil baja yang digunakan, penentuan lebar efektif, penentuan rasio modular, perhitungan propertis potongan melintang gelagar baja dan struktur komposit pada tengah bentang jembatan, perhitungan gelagar komposit dalam menahan lentur, perhitungan gelagar komposit dalam menahan gaya geser, pemeriksaan gelagar komposit dalam menahan gaya geser dan pemeriksaan gelagar komposit terhadap lendutan maksimum.

4) Merencanakan penghubung geser (Stud Connector).

5) Perencanaan diafragma rangka baja (batang atas, batang diagonal dan batang bawah)

6) Perencanaan dimensi perletakan.

\section{HASIL DAN PEMBAHASAN}

\section{A. Hasil observasi}

Adapun hasil dari observasi di lokasi yang akan dibangun didapat bahwa lebar sungai yang akan dilintasi adalah 17 meter, sehingga diperlukan jembatan dengan panjang bentang $20 \mathrm{~m}$ dan lebar jembatan $4.5 \mathrm{~m}$.

\section{B. Analisis Beban pada Slab Jembatan}

1. Formasi pembebanan slab untuk mendapatkan hasil momen maksimum pada bentang menerus. Momen maksimum pada slab jembatan dihitung dengan beban yang telah dihitung sebelumnya dengan hasil sebagai berikut:

QMS $=4,50 \mathrm{kN} / \mathrm{m}$ untuk berat sendiri slab jembatan

QMA $=4,29 \mathrm{kN} / \mathrm{m}$ untuk beban mati tambahan

$\Delta \mathrm{T} \quad=12,5^{\circ} \mathrm{C}$ untuk temperatur

PTT $=158 \mathrm{kN}$ untuk beban truk.

2. Momen pada slab lantai jembatan Tabel I

Hasil Momen pada Slab jembatan

\begin{tabular}{|c|c|c|c|c|c|c|}
\hline b & Jeirßeban & $\begin{array}{l}\text { Faltor } \\
\text { Beball }\end{array}$ & $\begin{array}{l}\text { Daya } \\
\text { Layan }\end{array}$ & $\begin{array}{c}\text { Kexdhaul } \\
\text { Ultimit }\end{array}$ & $\begin{array}{l}\text { Moppum } \\
(\mathrm{km})\end{array}$ & $\begin{array}{l}\mathrm{Mh}_{\text {mppun }} \\
(\mathrm{KNm})\end{array}$ \\
\hline 1. & Beat sendiri & $\mathrm{K}_{\mathbb{I S}}$ & 1,0 & 1,3 & 0,297 & 0,593 \\
\hline 2 & Beban maitambahan & $K_{i / A}$ & 1,0 & 2,0 & 0,293 & 0,565 \\
\hline 3. & Bebon truk & $\mathrm{K}_{\mathrm{II}}$ & 1,0 & 2,0 & 24,930 & 27,677 \\
\hline 4. & Beban angin & $\mathrm{K}_{2 \mathrm{~W}}$ & 1,0 & 1,2 & 0,160 & 0,177 \\
\hline 5 & Penganintemperatur & $\mathrm{K}_{\mathrm{EI}}$ & 1,0 & 1,2 & 0,011 & 0,002 \\
\hline
\end{tabular}


3. Kombinasi beban pada slab jembatan

Tabel II

\begin{tabular}{|c|c|c|c|c|c|c|}
\hline No & JenisBeban & $\begin{array}{l}\text { Falsor } \\
\text { Beban }\end{array}$ & $\begin{array}{c}\mathbf{M}_{\text {umpun }} \\
\text { (kNm) }\end{array}$ & $\begin{array}{c}\mathbf{M}_{\text {bpangam }} \\
\text { (kNm) }\end{array}$ & $\begin{array}{c}\mathrm{Mu}_{\text {mmpunu }} \\
(\mathrm{kNm})\end{array}$ & $\begin{array}{c}\mathrm{Mu}_{\text {lapamgmu }} \\
(\mathrm{kNm}\end{array}$ \\
\hline 1. & Berat sendiri & 1 & 0,593 & 0,297 & 0,771 & 0,386 \\
\hline 2. & Beban mati tambahan & 2 & 0,565 & 0,293 & 1,130 & 0,586 \\
\hline 3. & Bebantruk & 2 & 27,677 & 24,930 & 55,353 & 49,861 \\
\hline 4. & Beban angin & 1,0 & 0,177 & 0,160 & 0,177 & 0,160 \\
\hline 5. & Pengaruhtemperatur & 1,0 & 0,002 & 0,011 & 0,002 & 0,011 \\
\hline \multicolumn{5}{|c|}{ Total momen ultimit lombinas 1} & 57,434 & 51,004 \\
\hline
\end{tabular}

\begin{tabular}{|c|c|c|c|c|c|c|}
\hline No & JenisBeban & \begin{tabular}{|l} 
Falkor \\
Beban \\
\end{tabular} & $\begin{array}{c}\mathbf{M}_{\text {tumpuau }} \\
(\mathrm{kNm})\end{array}$ & $\begin{array}{c}\mathbf{M}_{\text {lapangnn }} \\
\text { (kNm) }\end{array}$ & 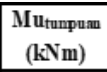 & $\begin{array}{c}\begin{array}{c}\mathbf{M} \mathbf{u}_{\text {lupangan }} \\
(\mathrm{kNm})\end{array}\end{array}$ \\
\hline 1. & Berasendiri & 1,3 & 0,593 & 0,297 & 0,771 & 0,386 \\
\hline 2. & Beban mai tambahan & 2 & 0,565 & 0,293 & 1,130 & 0,586 \\
\hline 3. & Beban truk & 1,0 & 27,677 & 24,930 & 27,677 & 24,930 \\
\hline 4. & Beban angin & 1,2 & 0,177 & 0,160 & 0,213 & 0,191 \\
\hline 5. & Pengaruh temperaur & 1,2 & 0,002 & 0,011 & 0,003 & 0,014 \\
\hline \multicolumn{5}{|c|}{ Totalmomenultimit lombinas่2 } & 29,793 & 26,108 \\
\hline
\end{tabular}

Hasil kombinasi 1 dan 2 beban pada slab jembatan

Dari hasil perhitungan kombinasi beban di atas maka diambil Mu maksimum pada daerah tumpuan adalah sebesar $\mathrm{kNm}$ dan untuk daerah lapangan sebesar $57,434 \mathrm{kNm}$.

\section{Penulangan slab}

Tulangan Lentur Negatif

Rasio tulangan yang diperlukan

$\rho=\frac{0,85 \times \mathrm{f} / \mathrm{c}}{\mathrm{fy}}=\left[1-\sqrt{1-\frac{2 \times \mathrm{Rn}}{0.85 \times \mathrm{f} / \mathrm{c}}}\right]=\frac{0,85 \times 25}{390}=\left[1-\sqrt{1-\frac{2 \times 2,637}{0,85 \times 25}}\right]=0,007$

Rasio tulangan minimum ( $\rho$ min)

(omin) $\rho_{\min }=\frac{1,4}{\mathrm{fy}}=\frac{1,4^{4}}{390}=0,004$

Nilai $\rho$ yang diambil adalah $=0,007$. Luas tulangan yang diperlukan (2.25). As $=\rho \times \mathrm{x} \mathrm{b} \mathrm{x} \mathrm{d}=$ $0,009 \times 1000 \times 165=1.195 \mathrm{~mm}^{2}$. Diameter tulangan yang digunakan D $16 \mathrm{~mm}$. Jarak tulangan yang diperlukan dihitung menggunakan persamaan:

$$
S=\frac{1}{4} \times \pi \times D^{2} \times \frac{b}{A s}=\frac{1}{4} \times \pi \times 16^{2} \times \frac{1000}{1.19}=168,188 \mathrm{~mm}
$$

Diambil jarak tulangan $150 \mathrm{~mm}$, sehingga digunakan tulangan D $16-150$.

Tulangan Lentur Positif

Rasio tulangan yang diperlukan $\rho=\frac{0.85 \times \mathrm{f} / \mathrm{c}}{\mathrm{fy}} \times\left[1-\sqrt{1-\frac{2 \times \mathrm{R}_{\mathrm{n}}}{0.85 \times f / \mathrm{c}}}\right]=\frac{0.85 \times \mathrm{f} / \mathrm{c}}{\mathrm{fy}} \times\left[1-\sqrt{1-\frac{2 \times \mathrm{R}_{\mathrm{n}}}{0.85 \times \mathrm{f} / \mathrm{c}}}\right]=0,008$

Rasio tulangan minimum ( $\rho$ min)

$$
\rho_{\min }=\frac{1.4}{f y}=\frac{1,4}{390}=0,004
$$

Nilai $\rho$ yang diambil adalah nilai yang terbesar $=$ 0,008

Luas tulangan yang diperlukan As $=\rho \times \mathrm{b} \times \mathrm{d}=$ $0,008 \times 1000 \times 165=1.320 \mathrm{~mm}^{2}$. Diameter tulangan yang digunakan D $16 \mathrm{~mm}$. Jarak tulangan yang diperlukan dihitung menggunakan persamaan

$$
S=\frac{1}{4} \times \pi \times D^{2} \times \frac{b}{A s}=\frac{1}{4} \times \pi \times 16 \times \frac{1000}{1320}=152,320 \mathrm{~mm}^{2}
$$

Diambil jarak tulangan 150mm, sehingga digunakan tulangan D 16 - 150 dengan luas tulangan yang dipakai:

$$
\text { As }=\frac{1}{4} \times \pi \times D^{2} \times \frac{b}{8}=\frac{1}{4} \times \pi \times 16 \times \frac{1000}{150}=1340,413 \mathrm{~mm}^{2}
$$

5. Kontrol lendutan slab

Lendutan total pada lantai jembatan

$\delta_{\text {tot }}=\delta_{\mathrm{g}}+\delta_{\mathrm{g}}<\mathrm{L}_{\mathrm{o}} / 240$

$\mathrm{Lx} / 240=1125 / 240=4,668 \mathrm{~mm}$

$\delta_{\text {tot }}=\delta_{g}+\delta_{g}=0,625+0,039=0,629 \mathrm{~mm}<4,668$ aman

5. Perhitungan pembebanan jembatan

1. Beban Tetap

Beban slab beton

Gaya geser

$\mathrm{V}_{\mathrm{MS} 1}=56,25 \mathrm{kN} . \mathrm{M}_{\mathrm{MS} 1}=281,25 \mathrm{kNm}$

Berat gelagar baja $\left(\mathrm{Q}_{\mathrm{MS} 2}\right)=2,960 \mathrm{kN} / \mathrm{m}$

Gaya geser

$\mathrm{V}_{\mathrm{MS} 2}=29,598 \mathrm{kNMomen} . \mathrm{M}_{\mathrm{MS} 2}=147,989 \mathrm{kNm}$

Beban Mati tambahan (QMA) $=4,29 \mathrm{kN} / \mathrm{m}]$

Gaya geser

$\mathrm{V}_{\mathrm{MA}}=42,9$ kNMomen. $\mathrm{M}_{\mathrm{MA}}=214,5 \mathrm{kNm}$ 
2. Beban Lalu Lintas Beban Truk

$\mathrm{M}_{\text {Max }}=\left(P_{1} \times y_{1}\right)+\left(P_{2} \times y_{2}\right)+\left(P_{3} \times y_{3}\right)=(25 \times 3)+(112,5 \times 5)+(112,5 \times 2,5)=918,75 \mathrm{kN}$

Beban Lajur D dan beban titik P

Gaya geser maksimum akibat beban $\mathrm{V}_{\mathrm{TT}}=97,569$ $\mathrm{kN}$. Momen maksimum akibat beban $\mathrm{M}_{\mathrm{TT}}=520,27$ $\mathrm{kNm}$

\section{Gaya Rem}

Gaya geser dan momen maksimum pada balok akibat gaya rem:

$$
\begin{aligned}
& \mathrm{M}=\mathrm{T}_{\mathrm{TB}} \times \mathrm{y} \\
& \mathrm{V}_{\mathrm{TB}}=\frac{\mathrm{T}_{\mathrm{TB}} \times \mathrm{y}}{\mathrm{L}}=\frac{50 \times 2,23}{20}=5,822 \mathrm{kN} . \mathrm{M}_{\mathrm{TB}}=\frac{1}{2} \times \mathrm{M}=\frac{1}{2} \times 116,44=58,22 \mathrm{kNn}
\end{aligned}
$$

\section{Kombinasi Pembebanan}

Tabel IV

\begin{tabular}{|c|c|c|c|c|c|c|}
\hline \multicolumn{2}{|l|}{ Jenis Beban } & $\mathrm{Vu}(\mathbf{k N})$ & $\mathrm{Mu}(\mathrm{kNm})$ & Faltor Beban & $\begin{array}{c}\text { Vu Terfaltor } \\
(\mathrm{kN})\end{array}$ & $\begin{array}{l}\text { Mu Terfaltor } \\
(\mathrm{kNm})\end{array}$ \\
\hline Berat sendiri & \begin{tabular}{l|l}
$\mathrm{MS}$ \\
\end{tabular} & & & & & \\
\hline Slab beton & $\mathrm{MS}_{1}$ & 56250 & 281.250 & 1.3 & 73.125 & 365.625 \\
\hline Gelagar baja & $\mathrm{MS}_{2}$ & 29.598 & 147.989 & 1.1 & 32.558 & 162.788 \\
\hline Matit tambahan & MA & 42900 & 214.500 & 2 & 85.800 & 429.000 \\
\hline Susut dan rangkak & SR & 2.200 & 20.725 & 1 & - & 20.725 \\
\hline Lalu lintas & TD & 97569 & 520.271 & 1.8 & 175.624 & 936.488 \\
\hline & $\mathrm{BR}$ & 6.262 & 62.624 & 1.8 & 11.272 & 112.723 \\
\hline Gesekan perletalan & $\mathrm{FR}$ & & 6.437 & 1.3 & & 8.369 \\
\hline Temperatur & ET & 10.431 & 208.616 & 1.2 & 12.517 & 250.339 \\
\hline Angin & $\mathrm{EW}$ & & 87.347 & 1.2 & & 104.816 \\
\hline Gemprome & EO & 6437 & 32187 & 1 & 6437 & 32187 \\
\hline
\end{tabular}

Gaya-gaya geser serta momen ultimit dan faktor

\section{Tabel V}

Kombinasi gaya geser rencana gelagar tengah

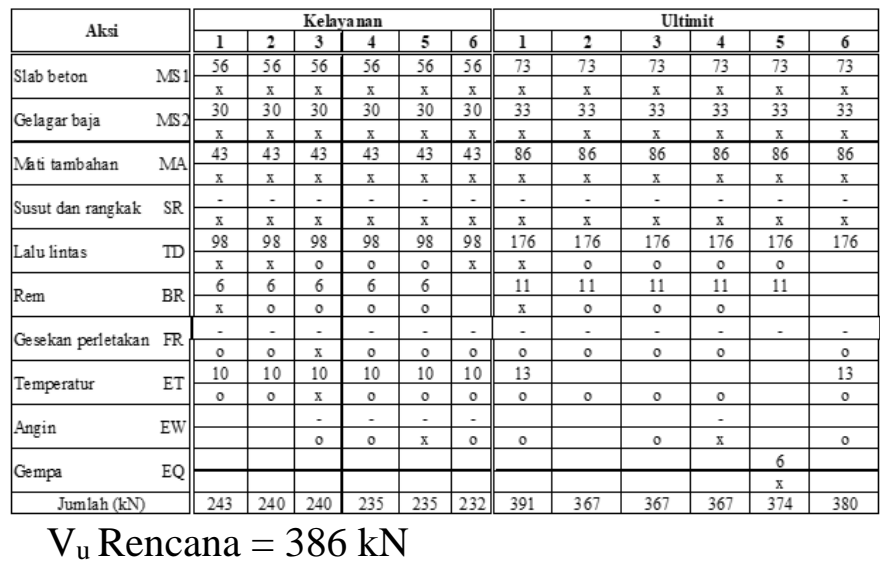

Tabel VI

Kombinasi momen rencana

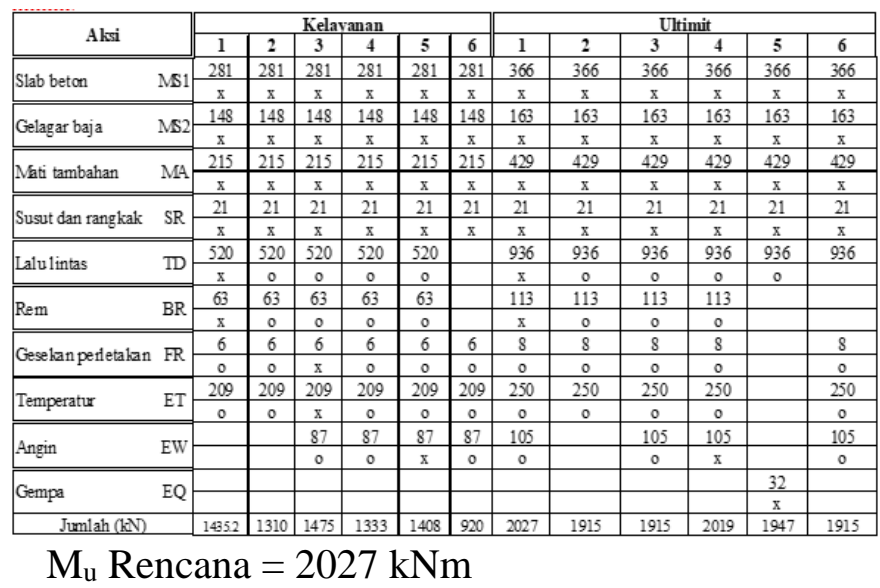

C. Perhitungan Kekuatan Gelagar Komposit

1. Data profil baja

Dari hasil percobaan perhitungan kebutuhan profil didapat dimensi profil yang diperlukan ialah profil WF 800 × $300 \times 14$ × 26 dengan spesifikasi sebagai berikut: Berat profil $w d=292 \mathrm{~kg} / \mathrm{m}$, Tinggi profil ds $=800 \mathrm{~mm}$, lebar sayap $\mathrm{bf}=300 \mathrm{~mm}$, tebal badan $\mathrm{tw}=14 \mathrm{~mm}$, tebal sayap $\mathrm{tf}=26 \mathrm{~mm}, \mathrm{r} 0=28$ $\mathrm{mm}$, Luas penampang $\mathrm{As}=26740 \mathrm{~mm} 2$, Ix = 2.920.000.000 mm4, Iy = 117.000.000 mm4

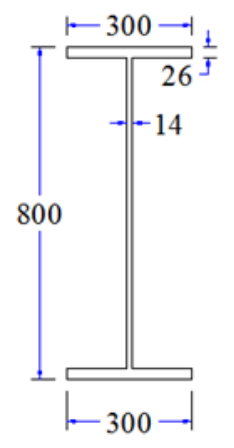

Gambar 3. Dimensi profil baja sebagai gelagar

a. Properti potongan melintang struktur komposit untuk kebutuhan beban jangka pendek (short term) $\mathrm{n}=9$ pada tengah bentang jembatan.

Lebar efektif plat beton $b E=1125 \mathrm{~mm}$.

$\mathrm{B}_{\mathrm{E}} / \mathrm{n}=1125 / 9=132 \mathrm{~mm}$ 
Luas penampang beton transformasi (Act) Act $=b_{E} / n \times t_{s}=1125 / 9 \times 200=26384,57 \mathrm{~mm}^{2}$ $\mathrm{y}^{\prime}$

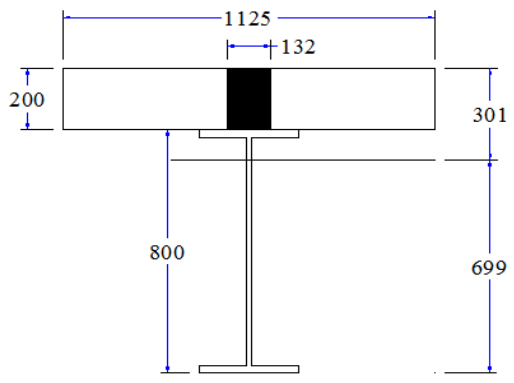
$=\Sigma \mathrm{Ay} / \Sigma \mathrm{A}$

Gambar 4 Letak garis netral struktur komposit dengan beban jangka pendek

2. Gelagar Komposit dalam menahan lentur

Kuat lentur nominal penampang $\left(\mathrm{M}_{\mathrm{n}}\right)$ untuk struktur gelagar komposit kompak pada bentang sederhana (simple spans) adalah sebagai berikut:

$$
\begin{aligned}
& M_{n}=C \times d=C \times\left(0,5 d_{s}+t_{s}-0,5 a\right) \\
& M_{n}=4.762 .125 \times((0,5 \times 800)+200-(0,5 \times 200)) \\
& M_{n}=2.381 .062 .500 N_{m m}=2.381 \mathrm{kNm}
\end{aligned}
$$

Setelah diketahui momen nominal $\left(\mathrm{M}_{\mathrm{n}}\right)$ diatas maka dapat dihitung momen resistensinya sebagai berikut:

$\mathrm{M}_{\mathrm{r}}=\phi \mathrm{M}_{\mathrm{n}}=0,9 \times 2.381 \mathrm{kNm}=2.143 \mathrm{kNm}$. Struktur gelagar komposit mampu memberikan kekuatan dalam menahan lentur sebesar $2.143 \mathrm{kNm}$

3. Gelagar Komposit dalam menahan gaya geser

Kemampuan gelagar komposit dalam menahan gaya geser: $\quad \mathrm{V}_{\mathrm{n}}=0,6 \quad \mathrm{f}_{\mathrm{y}}$ $\mathrm{A}_{\mathrm{w}}=0,6 \times 410 \times(800 \times 14)=2.755 .200 \quad \mathrm{~N}=2.755$ $\mathrm{kNV}_{\mathrm{r}}=\phi \mathrm{V}_{\mathrm{n}}=0,9 \times 2.755=2.480 \mathrm{kN}$

Struktur gelagar komposit mampu memberikan kekuatan dalam menahan gaya geser sebesar 2.480 $\mathrm{kN}$

$$
\begin{aligned}
& \text { D. Perencanaan Penghubung Geser } \\
& \text { (b_f } \times \text { VL) } / \mathrm{V}_{\mathrm{su}}=117.692 / 316.884=0,3714<1
\end{aligned}
$$

Maka digunakan jumlah minimal dalam satu baris yaitu 2 stud connector. Jarak antar stud connector arah memanjang adalah: persyaratan jarak antar stud connector arah memanjang berdasarkan SNI T-03-2005 yaitu:

$$
\mathrm{n} \leqslant 600 \mathrm{~mm} \quad \text { 2. } \mathrm{n} \leqslant 2 \times \mathrm{ts}=2 \times 200=400
$$

Berdasarkan syarat tersebut maka digunakan jarak antar stud connector arah memanjang adalah $400 \mathrm{~mm}$.

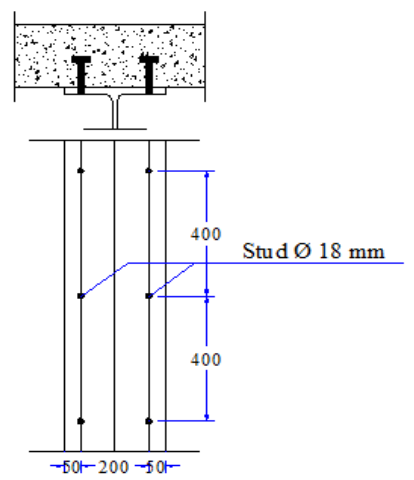

Gambar 5. Susunan penghubung geser

Persyaratan penghubung geser adalah:

$$
\begin{aligned}
& \text { V_L } \leqslant \phi V \_L S \\
& \text { V_LS }=0,55 \mathrm{n} \mathrm{V \_ su} \\
& \text { V_L } \leqslant \phi \times 0,55 \mathrm{n} \text { V_su } \\
& 392,31 \leqslant 0,9 \times 0,55 \times 2 \times 316.884 \\
& 392,31 \mathrm{~N} \leqslant 313,715 \mathrm{~N} \quad \text { Oke }
\end{aligned}
$$

Persyaratan sambungan pada gelagar

Dalam perencanaan ini digunakan panjang profil $12 \mathrm{~m}$ (dipotong menjadi $10 \mathrm{~m}$ ) sehingga untuk panjang jembatan $20 \mathrm{~m}$ dan terdapat satu buah sambungan gelagar. Letak smbungan diatur dengan jarak $10 \mathrm{~m}+10 \mathrm{~m}$.

Adapun data-data yang dibutuhkan dalam perencanaan sambungan gelagar antara lain:

Momen ultimit, Mu 2.012,19 kNm.Gaya geser ultimit, $\mathrm{Vu} 385,99 \mathrm{kN}$, Diameter baut yang digunakan, $\mathrm{D}=20 \mathrm{~mm}$. Pelat yang digunakan baja mutu Dengan fy $=410 \mathrm{Mpa}$, ketebalan pelat, $\mathrm{t}=$ $10 \mathrm{~mm}$

1. Perencanaan pada bagian pelat badan Perhitungan kekuatan baut dalam geser untuk baut dengan diameter $20 \mathrm{~mm}$ diperoleh data sebagai berikut: 
Gaya tarik, T

$$
=145000 \mathrm{~N}
$$

Luas inti baut, Ae $=225 \mathrm{~mm}^{2}$

Luas untuk menghitung kekuatan tarik As= 245 $\mathrm{mm}^{2}$

Luas bagian polos nominal baut, $\mathrm{A}_{0}=314 \mathrm{~mm}^{2}$

$$
\mathrm{f}_{\mathrm{uf}}=\mathrm{T} / \mathrm{A}_{\mathrm{s}}=145000 / 225=591,84 \mathrm{Mpa}
$$

Kekuatan geser baut:

$\mathrm{V}_{\mathrm{f}}=0,62 \quad \mathrm{f}_{\mathrm{uf}} \quad \mathrm{kr} \quad\left(\mathrm{n}_{\mathrm{n}} \mathrm{A}_{\mathrm{e}}+\mathrm{n}_{\mathrm{x}} \mathrm{A}_{0}\right)=0,62 \times 591,84 \times 1$ $(2 \times 225+2 \times 314)=395,56 \mathrm{kN}$

2. Perhitungan kekuatan pelat sambung dalam menahan gaya tumpu

Kuat tumpu pelat sambung:

V_b $=3,2$ d_f t_p f_up $=3,2 \times 20 \times 10 \times 550=352.000$ $\mathrm{N}=352 \mathrm{kN}$. Gaya geser pelat badan untuk perencanaan sambungan pada daerah pelat badan dihitung dengan persamaan :

V_nw $=\varnothing$.f_y. A_w $=0,75 \times 410 \times 6720=2.066 .000$ $\mathrm{N}=2.066 \mathrm{kN}$. Jumlah baut yang dibutuhkan pada pelat badan adalah

n=V_nw/V_(b ) $=2,066 / 352=5,9$ buah

Digunakan 6 buah baut dalam 1 baris, pada pelat badan digunakan 12 baris. Sehingga jumlah keseluruhan baut adalah 72 buah baut.

Penentuan jarak antar baut berdasarkan SNI T03-2005

Jarak antar baut harus memenuhi:

$2,5 \mathrm{df} \leqslant \mathrm{s} \leqslant 15$ tp atau $200 \mathrm{~mm}$

$2,5 \times 20 \leqslant \mathrm{~s} \leqslant 15 \times 10$ atau $200 \mathrm{~mm}$

$50 \leqslant \mathrm{~s} \leqslant 150$ atau $200 \mathrm{~mm}$

Digunakan jarak s $60 \mathrm{~mm}$ Jarak baut dengan tepi pelat (s) harus memenuhi:

$1,5 \mathrm{df} \leqslant \mathrm{s} \leqslant(4 \mathrm{tp}+100)$ atau $200 \mathrm{~mm}$

$1,5 \times 20 \leqslant \mathrm{~s} \leqslant(4 \times 10+100) 200 \mathrm{~mm}$

$30 \leqslant \mathrm{~s} \leqslant 140$ atau $200 \mathrm{~mm}$

Digunakan jarak s $=50 \mathrm{~mm}$

2. Perencanaan pada bagian pelat sayap

Pelat sambung pada sayap didesain sebagai batang tarik. Digunakan pelat dengan material baja mutu BJ 55 dengan fy= $410 \mathrm{Mpa}$ dan $\mathrm{fu}=550 \mathrm{Mpa}$. Ketebalan pelat yang digunakan adalah $15 \mathrm{~mm}$.

1. Perhitungan kekuatan baut dalam menahan gaya tarik.

Kekuatan nominal satu buah baut $\left(\mathrm{N}_{\mathrm{tf}}\right)$ yang memikul gaya tarik harus memenuhi persamaan sebagai berikut:

$\mathrm{N}_{\mathrm{tf}}=\mathrm{A}_{\mathrm{s}} \times \mathrm{f}_{\mathrm{uf}}=245 \times 591,84=145.000 \quad \mathrm{~N}=145 \mathrm{kN} 2$. Perhitungan kekuatan pelat sambung pada sayap

Kekuatan pelat sambung harus diperiksa terhadap kekuatan tumpu berdasarkan persamaan berikut:

$\mathrm{V}_{\mathrm{b}}=3,2 \times \mathrm{d}_{\mathrm{f}} \times \mathrm{t}_{\mathrm{p}} \times \mathrm{f}_{\mathrm{up}}=3,2 \times 20 \times 15 \times 550=145.000 \mathrm{~N}$

Kekuatan baut dalam tarik menentukan dalam perhitungan jumlah baut yang dibutuhkan. Jumlah baut yang dibutuhkan pada pelat sayap (n) adalah:

$$
\mathrm{n}=\mathrm{T}_{\mathrm{tf}} / \mathrm{N}_{\mathrm{tf}}=8860,551 / 145=61,11 \text { buah }
$$

Digunakan 64 baut dan diatur dalam 4 baris. Sehingga dalam 1 barus terdapat 16 baut. Pengaturan jarak antar baut adalah sebagai berikut:

Jarak antar baut $50 \leqslant \mathrm{~s} \leqslant 150$

Digunakan jarak, $\mathrm{s}=80 \mathrm{~mm}$

Jarak antara baut dengan tepi pelat $30 \leqslant s$ $\leqslant 140$

Digunakan jarak, $\mathrm{s}=40 \mathrm{~mm}$

E. Perencanaan Diafragma

Data yang diperlukan dalam perencanaan diafragma antara lain:

Jarak antar diafragma, L 2,5 m. Besar gaya angin ultimit 130,922 kN. Besar gaya gempa horizontal = $\mathrm{kh} \times \mathrm{wt}=0,084 \times 270,5=21,63 \mathrm{kN}$

Penataan letak diafragma direncanakan sebagai berikut: 


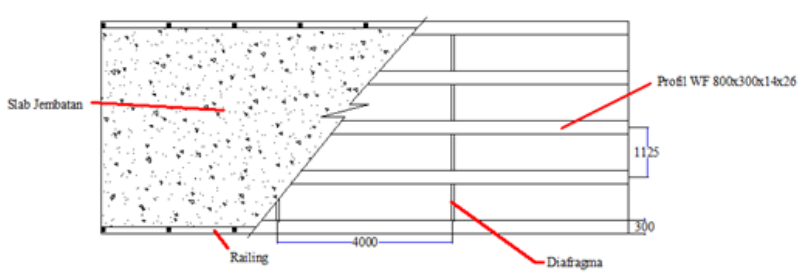

Gambar 6. Penempatan diafragma

Diafragma menahan gaya tekan aksial yang disebabkan oleh beban angin dan beban gempa. Besarnya gaya aksial tekan terfaktor yang diterima satu buah diafragma adalah:

$\mathrm{N}_{\mathrm{u}}=1,2 \mathrm{~T}_{\mathrm{ew}}+1,0 \mathrm{~T}_{\mathrm{EQ}}=(1,2 \times 145,254)+(1,0 \times 21,630)=$ $195,935 \mathrm{kN}$

Gaya tersebut bekerja sepanjang bentang jembatan. Sehingga gaya yang diterima diafragma per meter $\mathrm{N}_{\mathrm{u}} / \mathrm{L}=(195,935) / 20=9,797 \mathrm{kN}$

1. Perencanaan batang atas

Digunakan profil siku $70 \times 70 \times 7$ dengan As $=940 \mathrm{~mm} 2, \mathrm{rmin}=9 \mathrm{~mm} \mathrm{~L}=1.300 \mathrm{~mm}$ dengan mutu baja BJ 41, fy = $250 \mathrm{Mpa}$.

Memeriksa kelangsingan batang tekan,

$$
\begin{aligned}
& \lambda=(\mathrm{k} . \mathrm{L}) / \mathrm{r}=(0,7 \times 1125) / 9=87,5 \\
& \lambda<140 \text { OK ! } \\
& \mathrm{b} / \mathrm{t}=70 / 7=10 \\
& 200 / \sqrt{ } \text { fy }=200 / \sqrt{ } 250=12,65 \\
& \mathrm{~b} / \mathrm{t}<200 / \sqrt{ } \text { fy Ok! }
\end{aligned}
$$

Menghitung kapasitas profil dalam menahan gaya tekan aksial:

$$
\lambda_{\mathrm{c}}=\frac{\lambda}{\pi} \sqrt{\frac{\mathrm{fy}}{\mathrm{E}}}=\frac{87,5}{\pi} \sqrt{\frac{250}{200000}}=0,98<1,5 \mathrm{Ok} !
$$

Kuat tekan dihitung dengan menggunakan persamaan :

$$
\begin{aligned}
& \mathrm{N}_{\mathrm{n}}=\left(0,66^{\lambda_{\mathrm{c}}{ }^{2}}\right) \times \mathrm{A}_{\mathrm{s}} \times \mathrm{f}_{\mathrm{y}}=\left(0,66^{0,98^{2}}\right) \times 940 \times 250=157,067 \mathrm{kN} \\
& \emptyset \mathrm{N}_{\mathrm{n}}=0,9 \times 157,067=141,36 \mathrm{kN} \\
& \emptyset \mathrm{N}_{\mathrm{n}} \geq \mathrm{N}_{\mathrm{tf}} \quad \text { Ok! }
\end{aligned}
$$

2. Perencanaan batang diagonal

Digunakan profil siku $70 \times 70 \times 7$ dengan As = $940 \mathrm{~mm}^{2}$, rmin $=9 \mathrm{~mm} \mathrm{~L}=956 \mathrm{~mm}$ dengan mutu baja BJ 41, fy = $250 \mathrm{Mpa}$.

Memeriksa kelangsingan batang tekan,

$$
\lambda=(\mathrm{k} . \mathrm{L}) / \mathrm{r}=(0,7 \times 956) / 9=74,36 \leqslant 140 \mathrm{Ok} \text { ! }
$$$$
\mathrm{b} / \mathrm{t}=70 / 7=10=200 / \sqrt{ } \mathrm{fy}=200 / \sqrt{ } 250=12,65
$$

\section{b/t $<200 / \sqrt{ }$ fy Ok!}

Menghitung kapasitas profil dalam menahan gaya tekan aksial:

$$
\lambda_{c}=\lambda / \pi \quad \sqrt{ }\left(f_{y} / E=\right) \quad 74,36 / \pi \quad \sqrt{ }(250 / 200000=)
$$

$0,8 \leqslant 1,5 \mathrm{Ok}$ !

Kuat tekan dihitung dengan menggunakan persamaan:

$$
\begin{aligned}
& N_{n}=\left(0,66^{0,8^{2}}\right) \times A_{s} \times f_{y}=\left(0,66^{0,8^{2}}\right) \times 940 \times 250=175,67 \mathrm{kN} \\
& \emptyset N_{n}=0,9 \times 175,67=158,11 \mathrm{kN} \\
& \emptyset N_{n} \geq N_{d} \quad \text { Ok! }
\end{aligned}
$$

3. Perencanaan batang bawah

Langkah perencanaan batang bawah sama seperti batang atas karena direncanakan menggunakan profil yang sama dengan panjang yang sama.

Besar gaya geser yang harus ditahan oleh baut merupakan gaya aksial diafragma sebesar

$$
\mathrm{V}=\mathrm{N}_{\mathrm{tf}}=62,70 \mathrm{kN}
$$

Diameter baut yang digunakan adalah $20 \mathrm{~mm}$ dan kekuatan satu baut berdasarkan perhitungan sambungan gelagar didapatkan :

$$
\mathrm{V}_{\mathrm{f}}=395,56 \mathrm{kN}
$$

\section{F. Perencanaan Perletakan}

Elastomer direncanakan berdasarkan beban vertikal yang bekerja. Dari hasil perhitungan diperolah beban vertikal maksimum pada tumpuan jembatan sebesar $402,907 \mathrm{kN}$ atau sebesar 40 ton. Gunakan elastomer bearing produksi PT. Ralico Utama Rubber dengan dimensi 175 x $350 \mathrm{~mm}$ dengan maksimum jumlah lapisan adalah 3 lapis menggunakan ketebalan $12 \mathrm{~mm}$ setiap lapisnya. 
Dimensi elastomer ini mampu menahan beban vertikal sehingga 47,6 ton sehingga dimensi ini aman untuk digunakan pada konstruksi jembatan konposit Sungai Nipah ini.

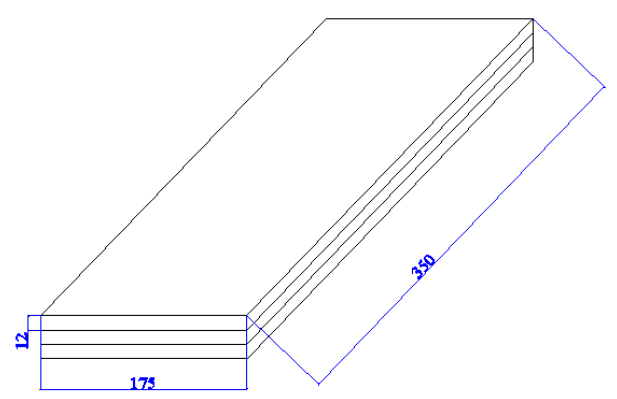

Gambar 8. Representasi ukuran bantalan elastomer
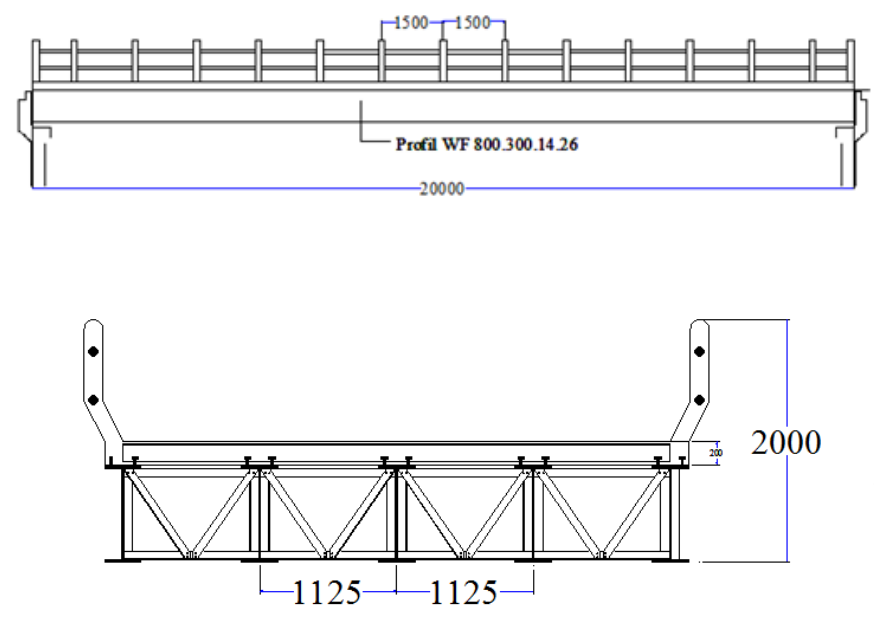

Gambar 9. Penampang memanjang dan melintang jembatan rencana

\section{KESIMPULAN}

Jembatan Sungai Nipah Desa Darul Aman Kecamatan Rupat dirancang dengan menggunakan struktur komposit antara beton dan baja. Adapun panjang bentang jembatan Sungai Nipah tersebut adalah $20 \mathrm{~m}$ dengan lebar 4,5 m. Dari hasil analisis serta perhitungan perencanaan jembatan tersebut didapatkan beberapa kesimpulan sebagai berikut (1) Digunakan gelagar baja utama 5 buah profil baja dengan tipe WF 800x300x14x26 mm dengan jarak antar girder 1,125 m. (2) Dari perhitungan diperoleh kekuatan momen pelat badan dalam menahan gaya terpusat adalah sebesar 2027 kNm dari kekuatan momen rencana maksimal yang dijinkan adalah sebesar $2143 \mathrm{kNm}$. Sedangkan gaya geser maksimal yang terjadi pada daerah tumpuan adalah sebesar $280 \mathrm{kN}$ dari kapasitas geser maksimal yang mampu dipikul oleh balok adalah sebesar $2480 \mathrm{kN}$. (3) Shear connector yang digunakan adalah stud dengan ukuran diameter $18 \mathrm{~mm}$ dengan jumlah 2 buah dalam satu baris. (4) Pada gelagar melintang (diafragma) digunakan profil L 70x70x7 mm dengan jarak antar diafragma adalah $4 \mathrm{~m}$. (5) Perencanaan elastomer bearing digunakan ukuran $175 \times 300 \times 12 \mathrm{~mm}$.

\section{UCAPAN TERIMA KASIH}

Terima kasih penulis ucapakan kepada rekanrekan yang turut serta membantu dalam penyelesaian jurnal perencanaan jembatan ini baik secara moral maupun meterial. Mudah-mudahan dapat memberikan manfaat dan dapat menjadi rujukan dalam perencanaan jembatan komposi serupa.

\section{REFERENSI}

SNIT-02-2005, Pembebanan Untuk Jembatan,BSN, Jakarta, 2005.

SNIT-03-2005, Perencanaan Struktur Baja Untuk Jembatan,BSN.

Hanif R, Desain Ulang Jembatan Liong Desa Bantan Tengah Menggunakan Struktur Komposit, Politeknik Negeri Bengkalis, Bengkalis, 2016

Setiawan A,Perencanaan Struktur Baja DenganMetode LRFD(Berdasarkan SNI 03-1729-2002), Penerbit AIRLANGGA, Jakarta,2008.

Zamri S, Perencanaan Jembatan Beton Bertulang Sungai Senderak Bengkalis Berdasarkan Sni T-02-2005, Politeknik Negeri Bengkalis, Bengkalis, 2016

AnggrainiA.J, “Analisis Desain Jembatan Komposit Gelagar Baja Menggunakan Struktur Non-Prismatik, 2015.

SNIT-12-2014, Perencanaan Struktur Beton Untuk Jembatan, putslitbang Jalan dan jembatan Dapartemen Pekerjaan Umum.

Pujianto A. Struktur Komposit dengan Metode LRFD, 2007.

Nasution T. Modul Kuliah Struktur Baja II, 2012.

Dinata. EI, Perencanaan Struktur Atas Jembatan Komposit Sungai Bengkalis, Politeknik Negeri Bengkalis, Bengkalis, 2012. 